\title{
Influence of wintering area on persistent organic pollutants in a breeding migratory seabird
}

\author{
Eliza H. K. Leat ${ }^{1, *}$, Sophie Bourgeon ${ }^{2}$, Ellen Magnusdottir ${ }^{3}$, Geir W. Gabrielsen ${ }^{4}$, \\ W. James Grecian ${ }^{1}$, Sveinn A. Hanssen ${ }^{2}$, Kristin Olafsdottir ${ }^{5}$, Aevar Petersen ${ }^{6}$, \\ Richard A. Phillips ${ }^{7}$, Hallvard Strøm ${ }^{4}$, Sandra Ellis ${ }^{8}$, Aaron T. Fisk ${ }^{8}$, \\ Jan Ove Bustnes ${ }^{2}$, Robert W. Furness ${ }^{1}$, Katrine Borgå ${ }^{9}$
}

${ }^{1}$ College of Medical, Veterinary and Life Sciences, Graham Kerr Building, University of Glasgow, Glasgow G12 8QQ, UK ${ }^{2}$ Norwegian Institute for Nature Research, FRAM Centre, 9296 Tromsø, Norway

${ }^{3}$ Institute of Biology, Askja, University of Iceland, Sturlugata 7, 101 Reykjavik, Iceland

${ }^{4}$ Norwegian Polar Institute, FRAM Centre, 9296 Tromsø, Norway

${ }^{5}$ Department of Pharmacology \& Toxicology, University of Iceland, 107 Reykjavik, Iceland

${ }^{6}$ Icelandic Institute of Natural History, 212 Gardabaer, Iceland

${ }^{7}$ British Antarctic Survey, Natural Environment Research Council, High Cross, Madingley Road, Cambridge CB3 0ET, UK

${ }^{8}$ Great Lakes Institute of Environmental Research, University of Windsor, Windsor, Ontario, N9B 3P4, Canada

${ }^{9}$ Norwegian Institute for Water Research, Gaustadalleén 21, 0349 Oslo, Norway

\begin{abstract}
As apex marine predators, seabirds are often sampled to monitor bioaccumulative persistent organic pollutants (POPs) in the marine environment. Despite the restrictions on use and production of many POPs, concern remains about levels of these chemicals present in marine biota due to their potential toxicity. Many seabird species are migratory, and although overwintering area has been hypothesized to affect the accumulation of POPs, few have studied the contribution of exposure in the wintering area on the POP burdens of seabirds. This study investigated the impact of wintering area on concentrations and patterns of organochlorines (OCs) and polybrominated diphenyl ethers (PBDEs) in plasma of breeding great skuas Stercorarius skua from 3 colonies; Bjørnøya (Svalbard), southeast Iceland and Shetland (Scotland). To do so, stable isotope values of primary feathers grown during the winter were used in conjunction with geolocator data $(n=16)$ to assign untracked individuals $(n=122)$, to 3 wintering areas (America, Europe and Africa). Birds wintering in Africa had lower plasma concentrations of many OCs and PBDE 47 compared to the other areas. Nevertheless, the influence of wintering area differed between contaminants and between breeding colonies. We conclude that although wintering area had a significant effect on both concentrations and patterns of POPs, its influence was small in comparison to differences in exposure to these pollutants at breeding colonies, but that accumulation of POPs during the winter may be important for specific populations of seabirds.
\end{abstract}

KEY WORDS: Great skua ·Stercorarius skua $\cdot$ Pesticides · PCBs · PBDEs · Feather stable isotopes · Geolocation

Resale or republication not permitted without written consent of the publisher

\section{INTRODUCTION}

Persistent organic pollutants (POPs) include a wide range of man-made chemicals which are persistent and bioaccumulate with the potential to cause ad- verse effects (Newman 2010). They are ubiquitous in the environment and have been detected in remote ecosystems, including the Arctic (de Wit et al. 2004). The use of several chlorinated pesticides and industrial chemicals was restricted by the Stockholm con- 
vention (UNEP 2001), implemented in 2004, and prior to this by individual governments. Flame retardant polybrominated diphenylethers (PBDEs), were added to the convention more recently (UNEP 2009). Given the longevity of POPs in the environment, the potential for adverse effects remains despite restriction of their use.

Seabirds are near the apex of most marine food chains and, compared to terrestrial top predators (Best et al. 2010), bioaccumulate high concentrations of POPs (Bustnes et al. 2003, Best et al. 2010, Leat et al. 2011). Concentrations of POPs in seabirds are usually analysed in samples obtained when the birds return to land to breed (e.g. Fisk et al. 2001, Helgason et al. 2008, Roscales et al. 2010). However, most seabirds that breed in temperate and Arctic regions are migratory (Gaston 2004) and may spend a high proportion of the year away from their breeding colonies. For example, Arctic terns Sterna paradisaea and pomarine skuas Stercorarius pomarinus are at sea for up to 9 mo each year (Furness 1987, Egevang et al. 2010). Although a number of studies have discussed the potential importance of migration in wildlife ecotoxicology (Buckman et al. 2004, Borgå et al. 2005a, Hebert et al. 2008), few have attempted rigorous analysis. Studies investigating the effect of migration on POP burdens in seabirds have focused mostly on differences between migratory and resident species within the same breeding locality (Buckman et al. 2004, Corsolini et al. 2011). However interspecies differences in diet and uptake of POPs and metabolism are confounding factors to the effect of wintering area in these studies (Fisk et al. 2001). Ideally the effect of wintering area on POP concentrations and pattern (the contribution of each POP to $\Sigma$ POPs) should be examined within a single seabird species that includes individuals with different migration strategies.

Developments in technology, including Global Location Sensor loggers, have made it possible to determine the wintering areas of individuals (Phillips et al. 2007, Egevang et al. 2010, González-Solís et al. 2011). Concentrations of POPs can be highly variable within a population, therefore a large sample size of tracked birds may be required to detect differences in POPs between seabirds wintering in different areas. However, the comparatively high cost of devices and sometimes low rate of retrieval can limit the sample sizes for tracked birds (Phillips et al. 2007, Magnusdottir et al. 2012).

Previous studies have successfully used intrinsic biomarkers such as stable isotopes to infer wintering areas of seabirds (Hebert et al. 2008, Phillips et al. 2009, González-Solís et al. 2011). The isotopic com- position of animal tissues reflects that of prey consumed during tissue formation. The nitrogen stable isotope ratio $\left({ }^{15} \mathrm{~N}:{ }^{14} \mathrm{~N} ; \delta^{15} \mathrm{~N}\right)$ can be used to indicate trophic level, as it shows a stepwise enrichment of the heavier isotope (Hobson \& Clark 1992, Bearhop et al. 2002, Post 2002), whereas the carbon stable isotope ratio $\left({ }^{13} \mathrm{C}:{ }^{12} \mathrm{C}_{i} \delta^{13} \mathrm{C}\right)$ reflects primary productivity and carbon source in the marine environment (Post 2002). As feathers are metabolically inert once formed, their isotopic values reflect a discrete time period. In most species of seabird flight feathers are moulted after the breeding season, usually in the wintering area (Phillips et al. 2009); therefore, primary feathers of adults sampled in the breeding season reflect the isotopic signatures of prey in their wintering area. However, it is difficult to assign a wintering area directly from isotope data alone due to lack of knowledge of variation between ocean areas in baseline $\delta^{15} \mathrm{~N}$ and $\delta^{13} \mathrm{C}$ values. Instead, information on the isotopic values of wintering areas from tracked individuals may be used to assign untracked individuals to particular wintering areas (Phillips et al. 2009, González-Solís et al. 2011).

Great skuas Stercorarius skua are good candidates to examine the effect of wintering areas on POP concentrations and patterns. These top predators are migratory, known to accumulate high concentrations of POPs (Leat et al. 2011) and moult their primary feathers during the winter (Furness 1987). They breed in colonies in the northeast Atlantic and winter in distinct areas within the Atlantic Ocean and surrounding coastal seas (Magnusdottir et al. 2012).

This study investigated the effect of wintering area on organochlorine (OC) and PBDE concentrations and patterns in plasma from breeding adults sampled at 3 colonies; Bjørnøya, Iceland and Shetland. Relating POP concentrations to wintering areas can contribute to our understanding of the factors underlying inter- and intra-species variations in POP levels, as well as document the potential bio-transport of POPs by seabirds.

\section{MATERIALS AND METHODS}

\section{Sampling and study sites}

Fieldwork was conducted in June 2008 and in June to July 2009 at 3 breeding colonies in the northeast Atlantic (Fig. 1); Bjørnøya in Svalbard, Norway $\left(74^{\circ}\right.$ $\left.29^{\prime} \mathrm{N}, 18^{\circ} 49^{\prime} \mathrm{E}\right)$, Öræfi, Iceland (635' $\left.\mathrm{N}, 16^{\circ} 29^{\prime} \mathrm{W}\right)$ and Foula in Shetland, Scotland $\left(60^{\circ} 08^{\prime} \mathrm{N}, 2^{\circ} 05^{\prime} \mathrm{W}\right)$. Geolocators attached to colour rings were deployed 


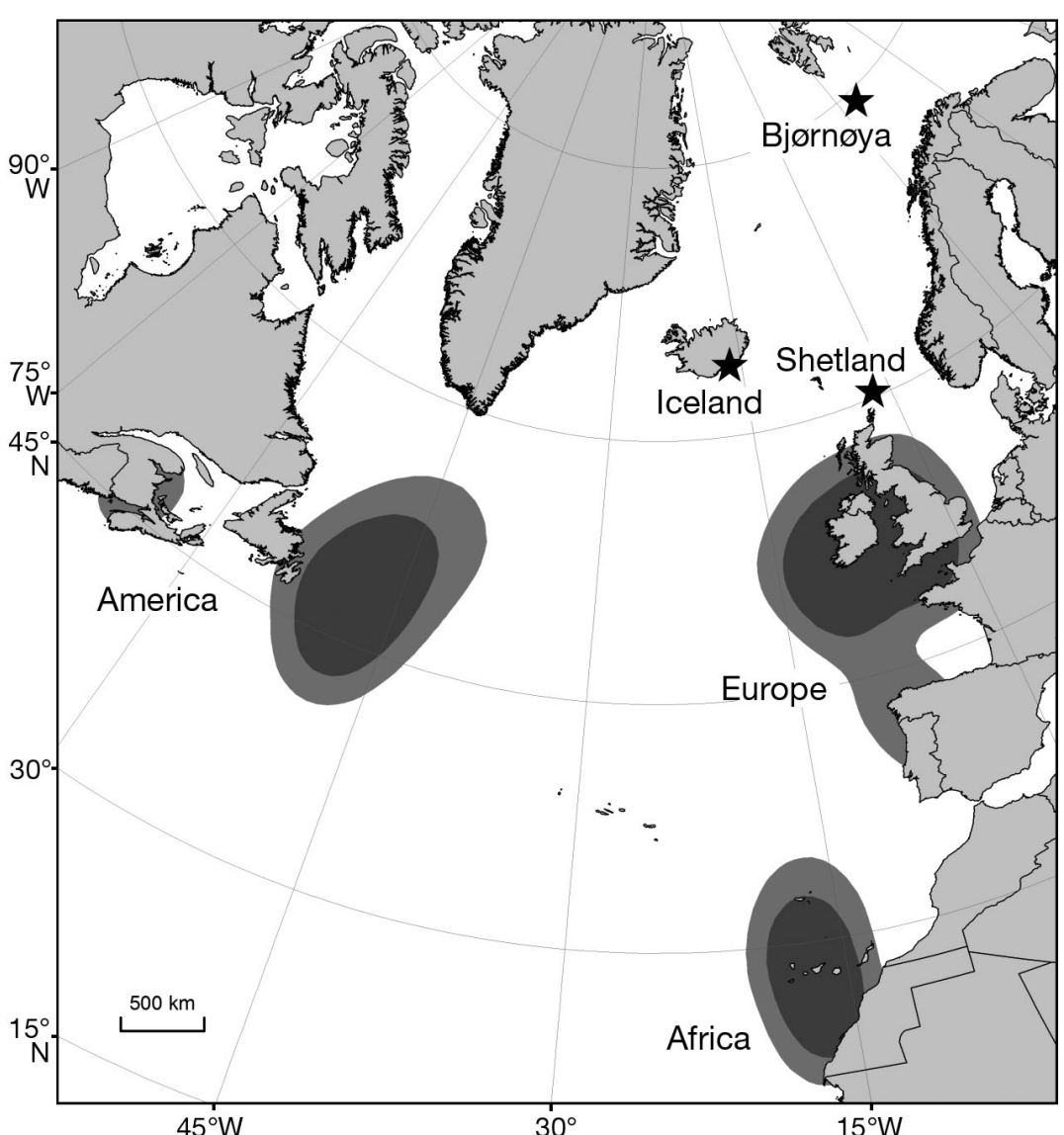

Fig. 1. Core overwintering areas (America, Europe and Africa) used by great skuas Stercorarius skua tracked from northeast Atlantic breeding colonies ( $\star$ ) during 2008-09, illustrated by the $50 \%$ (dark grey) and $75 \%$ (mid-grey) contours of a bivariate kernel distribution using a smoothing parameter $(h)$ of $200 \mathrm{~km}$ and cell size of $50 \mathrm{~km}$. Methods detailed in the Supplement at www.int-res.com/articles/suppl/m491p277_supp.pdf

on breeding adults in the 3 colonies (Iceland $\mathrm{n}=40$, Shetland $\mathrm{n}=16$, and Bjornoya $\mathrm{n}=24$ ) in 2008 and approximately $25 \%$ were recovered in 2009 (see Magnusdottir et al. 2012).

In 2009, breeding great skuas (19 equipped with loggers and 134 without) were caught on their nest using a remote-controlled noose trap. Upon capture a blood sample (maximum of $10 \mathrm{ml}$ ) was taken from the tarsal or brachial vein using a heparinized syringe. Blood was centrifuged within $3 \mathrm{~h}$ and the plasma and red blood cells (RBCs) were stored at $-20^{\circ} \mathrm{C}$ until chemical analysis could take place. Plasma was chosen as the sampling matrix for the measurement of POPs because blood sampling is non-lethal, allowing the continued study of individuals after sampling. Concentrations of OCs in blood correlate with those in internal tissues (Henriksen et al. 1998), and through mobilisation of lipid stores and their associated lipophilic POPs (Bustnes et al. 2012) plasma concentrations of POPs should reflect longer term exposure to POPs, as well as recent exposure. As great skua males regurgitate food to feed their mate (Furness 1987), pollutant exposure of partners is potentially correlated during breeding. Therefore, only 1 bird per nest was included in this study.

The 8th primary feather was removed from the left wing and part of the proximal unpigmented vane was used for stable isotope analysis (Michalik et al. 2010). Great skuas moult their primary feathers sequentially from the innermost outwards, starting in late autumn and progressing through the winter (Furness 1987), thus the isotope values of the 8th primary (the third outermost) represent those of the wintering area.

\section{Pollutant analysis and stable isotopes}

Pollutant and stable isotope analysis was carried out at The Great Lakes Institute for Environmental Research at the University of Windsor, Canada. POPs were extracted from plasma using a micro-extraction technique detailed in Daley et al. (2009) and sample clean-up was performed by florisil chromatography as described by Lazar et al. (1992). Extracts were analysed for individual organochlorines by gas chromatography electron capture detection following Daley et al. (2009). A Hewlett Packard HP 6890 gas chromatograph coupled with a Waters GCT-Premier Time of Flight (TOF) mass spectrometer was used for PBDE detection and analysis (Leat et al. 2011). The content of neutral lipids in the plasma was determined gravimetrically (Drouillard et al. 2004). Recoveries of the internal standard PCB 30 averaged $( \pm \mathrm{SD}) 69.8 \pm$ $9.7 \%$. Details of the pollutant and stable isotope methods and quality control information can be found in the Supplement at www.int-res.com/articles/suppl/ m491p277_supp.pdf.

\section{Molecular sexing}

Birds were sexed using DNA extracted from RBCs following a modified protocol of Griffiths et al. (1998) at the University of Glasgow, UK and the Norwegian 
University of Science and Technology, Trondheim, Norway. Sections of the sex-linked chromo-helicaseDNA-binding gene ( $c h d-W$ and $c h d-Z$ ) were amplified by polymerase chain reaction in Trondheim using primers 2550F/2718R (Fridolfsson \& Ellegren 1999) and in Glasgow using primers 2550F/2757R.

\section{Data analysis}

Univariate analysis was carried out in R v. 2.13.2 (R Core Development Team 2011) and multivariate statistics were carried out using CANOCO 4.5 for Windows (Ter Braak \& Šmilauer 2002a).

Location and length of non-breeding season. Geolocator data were downloaded and processed as detailed in Magnusdottir et al. (2012) to determine distribution of 19 tracked individuals in winter 2008-09 from 1 November to 1 February (defined as 'wintering period'). Stable isotopes of the 8th primary feather showed 3 isotopically distinct wintering areas (Fig. 2). Tracked birds which moved between these wintering areas $(n=3)$ were excluded from the data analysis as the location where the 8th primary was grown was unknown. To classify wintering areas by stable isotope values of the 8th primary feather, a linear discriminant function (lda), with jackknife procedure, was created using the 'Mass' package in $\mathrm{R}$ (Venables \& Ripley 2002). To reduce misclassification of untracked birds, any feather with a probability of group membership of less than 0.95 was left unclassified. The length of the non-breeding season com- pared to the breeding season will affect the proportion of the diet, and POPs contained therein, consumed in each habitat. Therefore departure from and return to the breeding colony was estimated from geolocation data for autumn and spring respectively. Additional details on the methods used for the geolocation analysis and lda can be found in the Supplement.

POPs. Concentrations of OCs and PBDEs $\left(\mu \mathrm{g} \mathrm{kg}^{-1}\right.$ wet weight) were corrected for percentage recovery of PCB 30 in individual samples. Pollutants were excluded from analysis if more than $30 \%$ of samples were below the detection limit, resulting in 42 OCs and PBDE 47 being included in the subsequent analysis (see Table S1 in the Supplement for full names and abbreviations). PCBs were grouped according to their configuration following Borgå et al. (2005b). The substitution of non-detects with zero or half the detection limit can introduce artificial patterns into the data which can interfere with model validation and invalidate statistical tests (Helsel 2004, Antweiler \& Taylor 2008). Therefore, for POPs with more than $30 \%$ of the samples above the detection limit the distribution of concentrations above the detection limit of an individual POP was used to replace non-detects in the data with modelled values from below the detection limit (Leat et al. 2013).

Influence of environmental variables on POPs. Six variables were included in the analyses to explain variation in $\mathrm{OC}$ and PBDE concentrations and patterns: wintering area, breeding colony, sex, percentage lipid content (\%lipid; OCs and PBDEs are

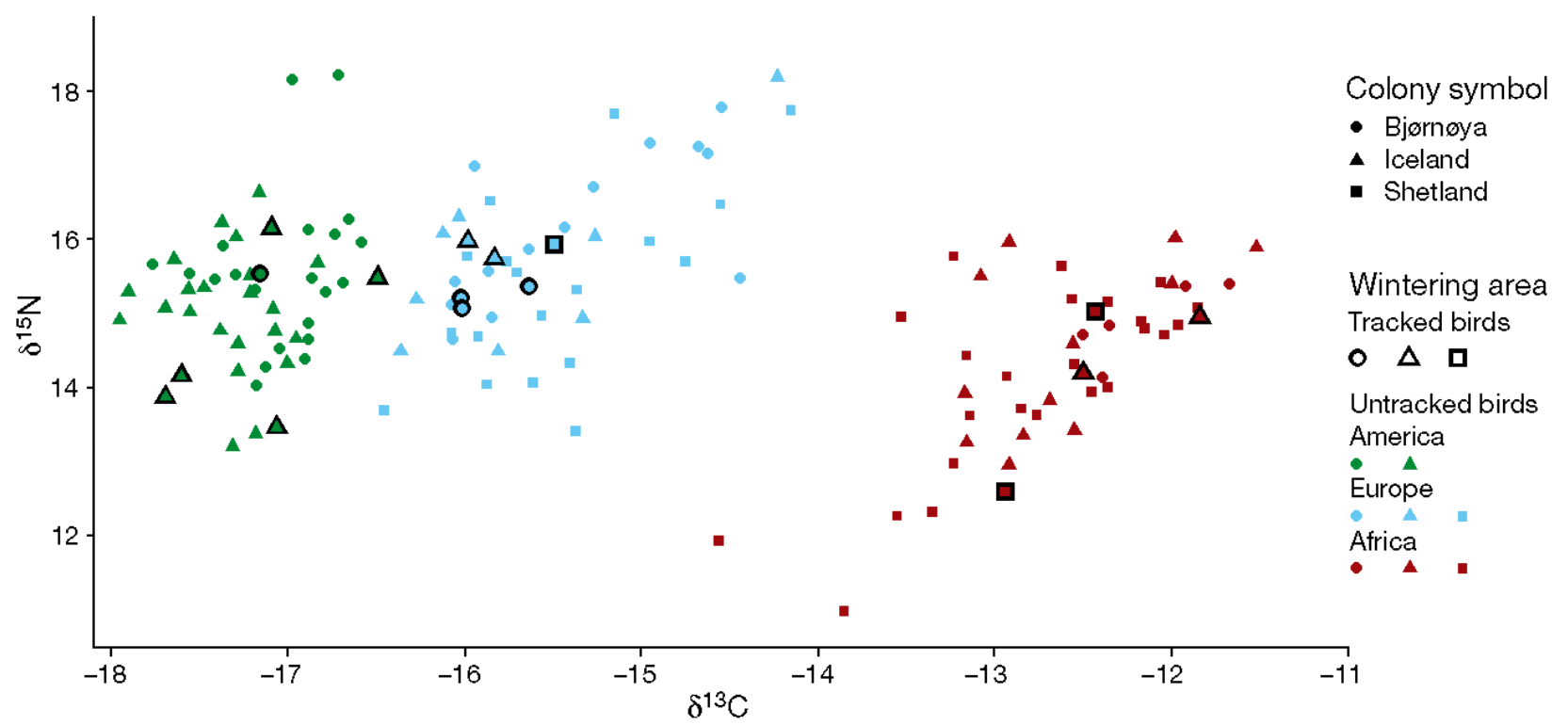

Fig. 2. Discrimination of wintering area in great skuas Stercorarius skua by $\delta^{15} \mathrm{~N}$ and $\delta^{13} \mathrm{C}$ of the 8th primary feather, grown during the winter. Feathers of breeding birds were sampled in 3 colonies; Bjørnøya, Iceland and Shetland 
lipophilic contaminants) and $\delta^{15} \mathrm{~N}$ and $\delta^{13} \mathrm{C}$ of $\mathrm{RBCs}$, representing breeding colony diet. As the emission profiles of OCs and PBDEs vary both temporally and spatially (Breivik et al. 2004), the effect of these explanatory variables on OCs and PBDEs were analysed separately. The effect of breeding colony on POPs in great skuas (Leat 2013) is not examined in detail here, but was included in the analysis to quantify the influence of breeding colony relative to wintering area.

$O C$ variation among colonies. Principal component analyses (PCAs) were carried out to reduce the complexity of the multivariate OC data. A PCA extracts components that are linear combinations of response variables (e.g. OC concentrations) reflecting the majority of variance in the data, thus reducing the multivariate data to a series of independent principal components (PC). To analyse variation in OC concentrations, data were log transformed to reduce heterogeneity and skewness, whilst variation in OC pattern, i.e. the relative contribution of individual OCs to the $\Sigma O C s$, was analysed using untransformed OC concentrations standardised by the norm in a separate PCA. The 1st and 2nd PCs (explaining the greatest proportion of variation) of each PCA were used as response variables in general linear models, where full models included wintering area, breeding colony, wintering area $\times$ breeding colony, sex and $\%$ lipid as explanatory variables. Stable isotope ratios of RBCs were not included as explanatory variables in analysis of variation among colonies, as no stable isotope baseline (Jardine et al. 2006) could be established for the 3 breeding colonies. Model selection was carried out by backwards stepwise selection and model validation by visual inspection of residuals and use of Shapiro-Wilk normality tests. Tukey's post hoc tests were used to make pairwise comparisons for significant variables. Model fit $\left(\mathrm{R}^{2}\right)$ for each significant variable was calculated using Type II sums of squares.

$O C$ variation within colony. Due to high variation in OC concentrations between colonies, patterns in OC concentrations within each colony may be obscured when data from all colonies are analysed together using multivariate analysis. Therefore, data were also analysed for each colony individually using redundancy analysis (RDA). RDA is a multivariate analysis similar to PCA, but constrained by including active explanatory variables in addition to the response (here: OC data). The RDA extracts axes minimizing the total residual sum of squares among all response variables, and assigns scores to the samples that are linear combinations of the OC concentra- tions and significant explanatory variables. This in effect combines the 2-step analysis performed with data from all together colonies, but is less suited to investigating interactions (e.g. wintering area $x$ breeding colony) as levels of categorical variables are added individually to the analysis. Significant explanatory variables were chosen by forward selection using Monte Carlo permutation tests with 499 unrestricted permutations and a significance level of $p<0.05$. Birds with explanatory variables which had an influence of more than 5 times the average leverage in the RDA ( $>3$ SD from the mean; Ter Braak \& Šmilauer 2002b) were excluded from the analysis. For a more detailed description of RDA, PCA and diagram interpretation see Lepš \& Šmilauer (2003).

PBDEs among and within colonies. Analysis of PBDEs was carried out using general linear models with ln-transformed data, first among colonies and then within colony. Three individuals (Bjørnøya $\mathrm{n}=2$, Iceland $\mathrm{n}=1$ ) with all PBDEs below detection limits were identified as outliers in the analysis and in the positive correlation between $\Sigma O C$ s and PBDE 47 (Spearman's $\rho=0.529, \mathrm{~S}=219620, \mathrm{p}<0.001$ ). These were the only 3 samples to have concentrations of PBDE 47, the most common PBDE in this study, below detection and were excluded from the analysis, to meet the assumptions of a linear model.

\section{RESULTS}

\section{Location and length of non-breeding season}

The great skuas tracked using geolocators showed geographic segregation of primary feather stable isotope values (Fig. 2). Three distinct wintering areas were identified using stable isotopes in conjunction with geolocation data (Magnusdottir et al. 2012); continental shelf seas of North America close to Newfoundland, continental shelf seas west of Europe, and continental shelf seas northwest of Africa (Fig. 1). Hereafter these marine areas are referred to by their adjacent land masses; America, Europe and Africa.

Separation of wintering areas by feather stable isotopes was particularly noticeable in $\delta^{13} \mathrm{C}$ between Europe and Africa (Fig. 2). The most successful discriminant function for identifying wintering area using feather stable isotopes of tracked birds $(\mathrm{n}=16)$ incorporated both $\delta^{15} \mathrm{~N}$ and $\delta^{13} \mathrm{C}$ (see Supplement for details). When this discriminant function was applied to the stable isotope ratios in feathers of untracked birds, 125 were classified and are shown in Fig. 2. 
Only 10 birds $(7 \%)$ remained unclassified, with $\mathrm{p}<0.95$, all of which had isotopic values intermediate between those of America and Europe and were excluded from subsequent analysis.

There were differences in the proportion of great skuas from different colonies that used each wintering area (Fig. 3). Birds from Bjørnøya wintered mostly off America $(n=23)$ and Europe $(n=17)$ with a few off Africa $(n=5)$. Half of the birds from Iceland wintered off America $(n=27$ ) whereas the remaining birds migrated either to Europe $(\mathrm{n}=10)$ or Africa ( $\mathrm{n}=14$ ). In contrast, birds from Shetland did not winter in America: approximately half wintered off Europe $(n=19)$ and the remainder off Africa $(n=22)$. There was no difference in the sex ratio among birds wintering in different areas for birds from Iceland (Fisher's exact test $\mathrm{p}=0.30$ ) or Shetland $(\mathrm{p}=1$ ), whilst more male birds from Bjørnøya wintered off America than elsewhere $(\mathrm{p}=0.02)$.

Tracked birds from Iceland spent an average of 7.5 mo away from the colony (mid-August to the beginning of April) and sampling took place in midJune, 2.5 mo after returning to the colony. Birds from Shetland left the colony in mid-September and returned 7 mo later in mid-April; they were sampled
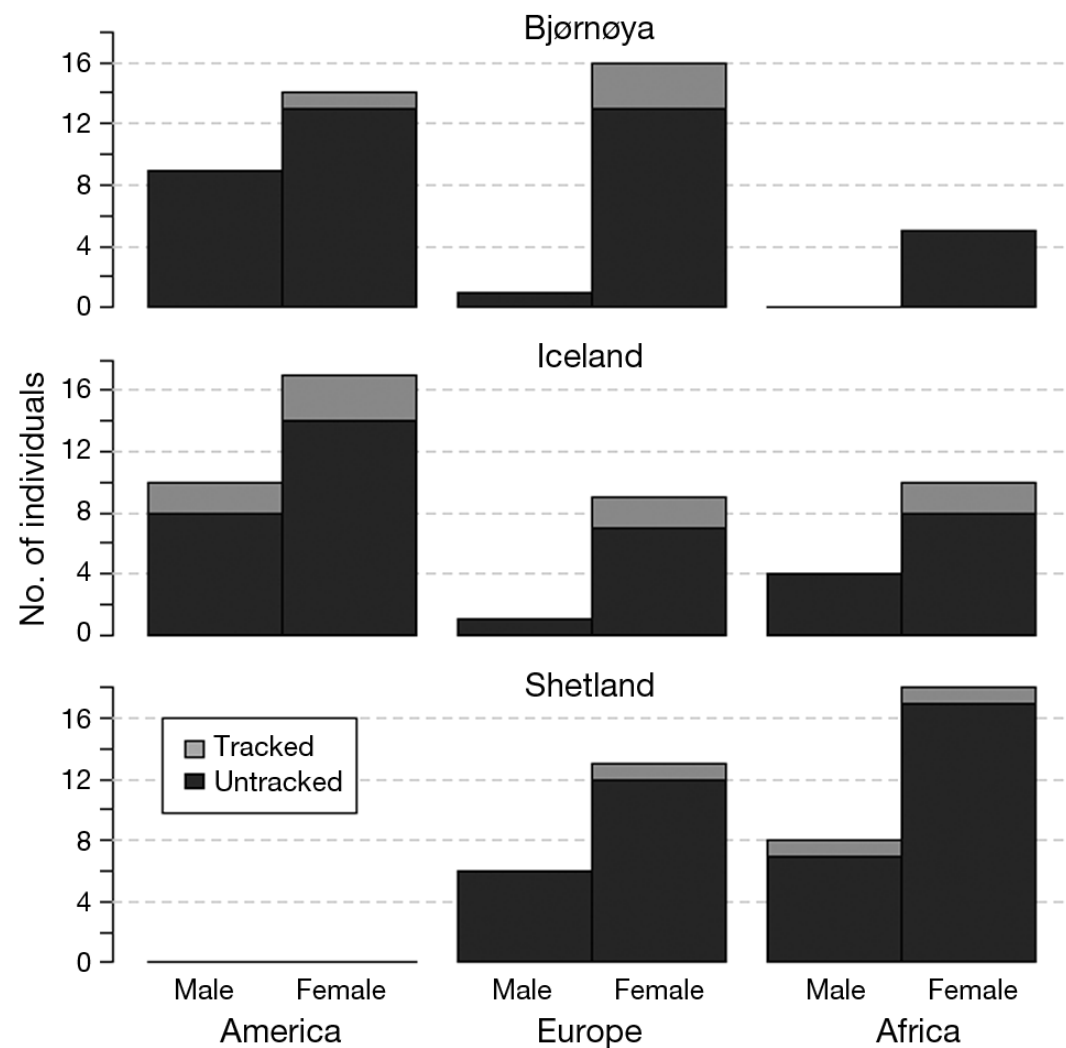

Iceland

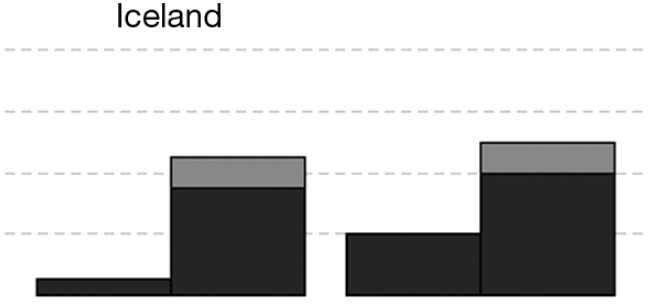

Shetland



Fig. 3. Wintering areas of male and female great skuas Stercorarius skua from 3 breeding colonies in the northeast Atlantic in mid-June. Birds tracked from Bjørnøya departed in late September but after 27 March were at latitudes with constant daylight and so their location could not be estimated. Locations obtained before this date indicate the birds had not yet returned to the colony; thus these birds spent a minimum of 6 mo away from the colony and a maximum of 3 mo at the colony prior to sampling in late June and early July.

\section{Influence of explanatory variables on POP concentrations and patterns}

Concentrations of OCs and PBDE 47 of 141 birds, by colony and wintering area, are presented in Table 1. Wintering area had a significant effect on both concentration and pattern (the contribution of each OC to $\Sigma$ OCs) of POPs in great skuas (Tables 2 $\& 3)$. When data from all colonies were analysed together, wintering area had a greater effect on the pattern (14.4\% of variation explained, PC1 and PC2 combined) than on the concentrations of OCs (3.3\%) and PBDE 47 (8.7\%). Overall, breeding colony had a greater effect on OC (53\%) and PBDE 47 concentrations $(13 \%)$ than did wintering area, but a smaller effect on the pattern of OCs (5\%). Sex had a small but significant effect on OC $(7.7 \%)$ and PBDE 47 concentrations $(3.6 \%)$, and OC pattern $(1.4 \%)$.

OC concentrations. When all colonies were considered, a PCA of OC concentrations explained $85 \%$ of variation along PC1 and $4 \%$ along PC2. These 2 PCs represent 2 independent composite variables explaining variation in OC concentrations; most OCs were strongly correlated with PC1, whilst trans-nonachlor was more strongly correlated with PC2 (see the Supplement; Table S3 and Fig. S1a for PC loadings and ordination diagram, respectively). Concentrations of OCs representative of $\mathrm{PC} 1$ and $\mathrm{PC} 2$ are presented in Fig. $4 \mathrm{a}, \mathrm{b}$, grouped by breeding colony and wintering area.

In a general linear model, wintering area, breeding colony and sex were all significant in explaining variation in PC1 (Table 3); there was no interaction between wintering area and breeding colony. Differences in OC concentrations were found across colonies between birds wintering off Africa and 


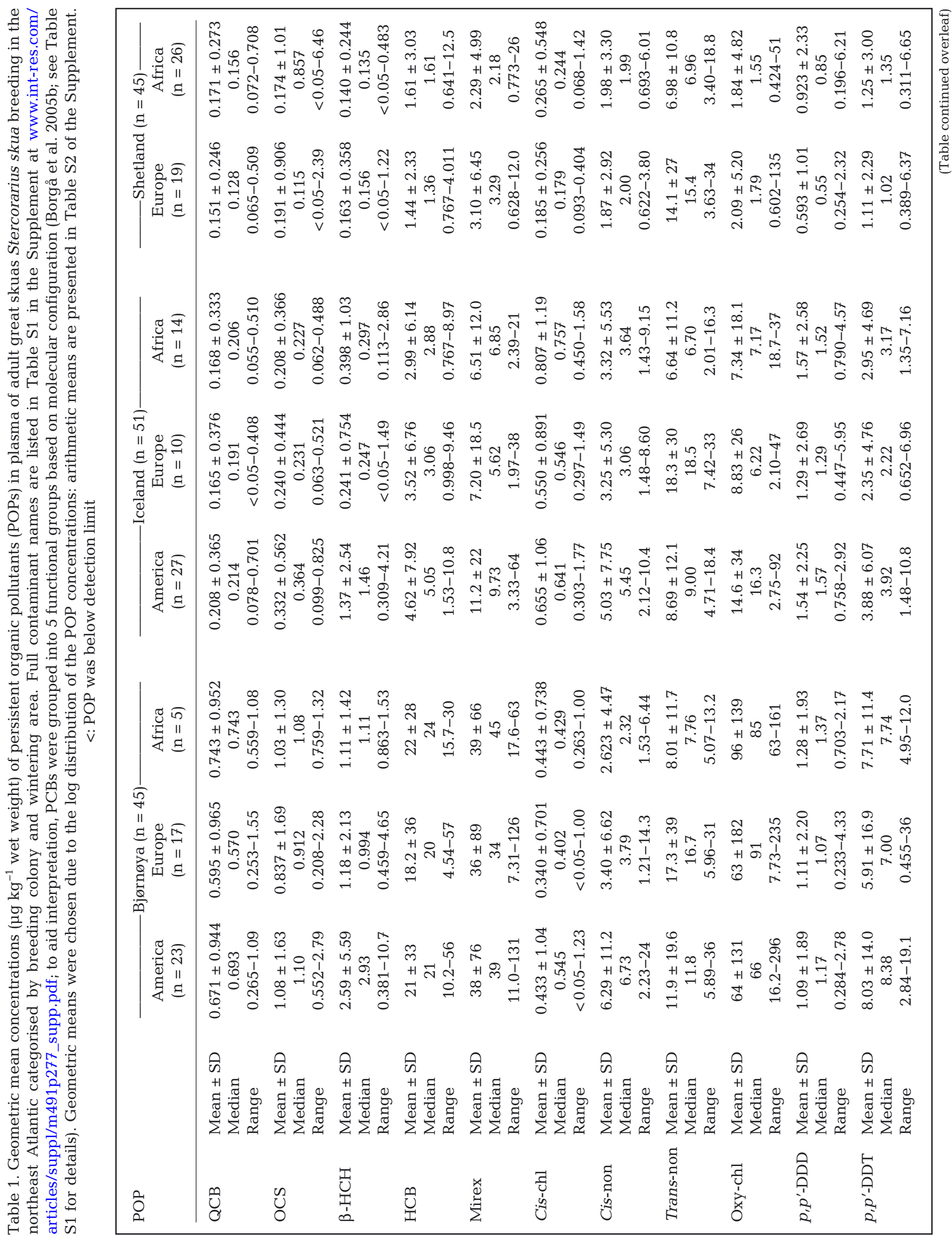




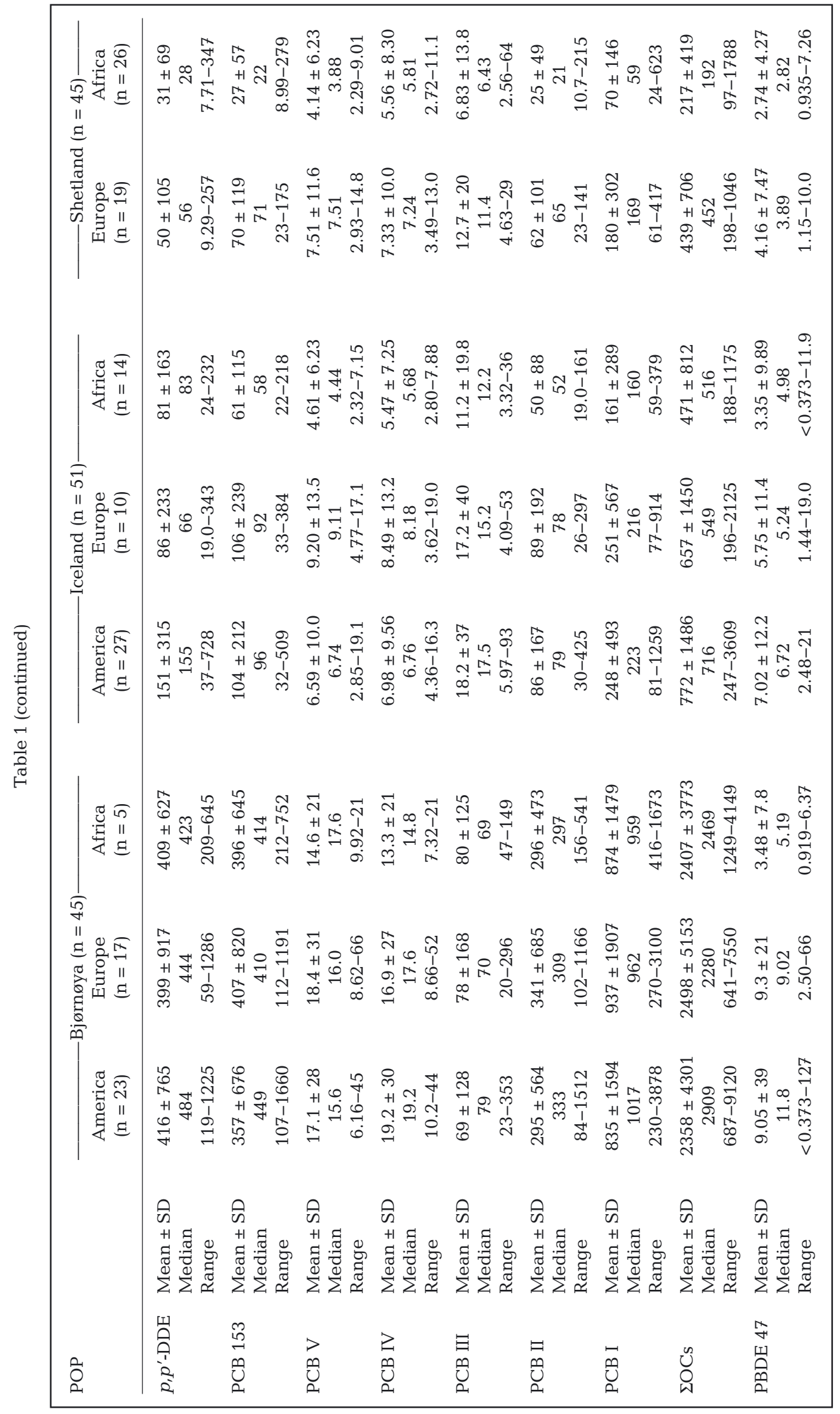


Table 2. General linear model analysis of the variation in concentrations of organochlorines (OCs) and PBDE 47 in great skua Stercorarius skua plasma. Individuals were sampled from 3 different colonies in the northeast Atlantic and wintered in 1 of 3 wintering areas. The 42 OCs measured were analysed using principal component analysis to produce 2 principal components (PC1 and PC2), the variation in which was analysed using general linear models. ns: not significant

\begin{tabular}{|c|c|c|c|c|c|c|c|c|}
\hline $\begin{array}{l}\text { Response } \\
\text { variables }\end{array}$ & $\begin{array}{l}\text { Explanatory } \\
\text { variables }\end{array}$ & $\mathrm{R}^{2}$ & $F$ & $\mathrm{df}$ & $\mathrm{p}$ & Post-hoc comparisons & $t$ & $\mathrm{p}$ \\
\hline \multirow[t]{2}{*}{$\begin{array}{l}\text { Model } 1 \\
\text { OCs - PC1 } \\
(85 \%)^{\mathrm{a}}\end{array}$} & Wintering area & 0.026 & 4.9 & 2,130 & $<0.001$ & $\begin{array}{l}\text { America vs. Europe } \\
\text { America vs. Africa } \\
\text { Europe vs. Africa }\end{array}$ & $\begin{array}{l}- \\
2.6 \\
2.8\end{array}$ & $\begin{array}{l}0.048 \\
0.031\end{array}$ \\
\hline & $\begin{array}{l}\text { Colony } \\
\text { Sex }\end{array}$ & 0.016 & 131 & $\begin{array}{l}2,130 \\
1,130\end{array}$ & $\begin{array}{l}<0.001 \\
<0.016\end{array}$ & $\begin{array}{l}\text { Bjørnøya vs. Iceland } \\
\text { Bjørnøya vs. Shetland } \\
\text { Iceland vs. Shetland }\end{array}$ & $\begin{array}{r}-11.9 \\
-15.3 \\
-5.2\end{array}$ & $\begin{array}{l}<0.001 \\
<0.001 \\
<0.001\end{array}$ \\
\hline \multirow[t]{3}{*}{$\begin{array}{l}\text { Model } 2 \\
\text { OCs - PC2 } \\
(4 \%)^{\mathrm{a}}\end{array}$} & Wintering area & 0.27 & 26 & 2,131 & $<0.001$ & $\begin{array}{l}\text { America vs. Europe } \\
\text { America vs. Africa } \\
\text { Europe vs. Africa }\end{array}$ & $\begin{array}{l}4.1 \\
- \\
7.1\end{array}$ & $\begin{array}{l}<0.001 \\
<0.001\end{array}$ \\
\hline & Colony & 0.057 & 5.6 & 2,131 & 0.005 & $\begin{array}{l}\text { Bjørnøya vs. Iceland } \\
\text { Bjørnøya vs. Shetland } \\
\text { Iceland vs. Shetland }\end{array}$ & $\begin{array}{c}- \\
2.7 \\
3.2\end{array}$ & $\begin{array}{l}0.36 \\
0.01\end{array}$ \\
\hline & Sex & ns & & & & & & \\
\hline $\begin{array}{l}\text { Model } 3 \\
\text { PBDE } 47\end{array}$ & Wintering area & 0.087 & 7.7 & 2,132 & $<0.001$ & $\begin{array}{l}\text { America vs. Europe } \\
\text { America vs. Africa } \\
\text { Europe vs. Africa }\end{array}$ & $\begin{array}{l}- \\
3.6 \\
3.2\end{array}$ & $\begin{array}{l}0.003 \\
0.01\end{array}$ \\
\hline & Colony & 0.13 & 11.3 & 2,132 & $<0.001$ & $\begin{array}{l}\text { Bjørnøya vs. Iceland } \\
\text { Bjørnøya vs. Shetland } \\
\text { Iceland vs. Shetland }\end{array}$ & $\begin{array}{c}-3.0 \\
-4.7 \\
-\end{array}$ & $\begin{array}{c}0.02 \\
<0.001\end{array}$ \\
\hline
\end{tabular}

Table 3. General linear model analysis of the variation in the pattern of organochlorines (OCs) in great skua Stercorarius skua plasma. Individuals were sampled from 3 different colonies in the northeast Atlantic and wintered in 1 of 3 wintering areas. The 42 OCs measured were analysed using principal component analysis to produce 2 principal components (PC1 and PC2), the variation in which was analysed using general linear models. ns: not significant

\begin{tabular}{|c|c|c|c|c|c|c|c|c|}
\hline $\begin{array}{l}\text { Response } \\
\text { variables }\end{array}$ & $\begin{array}{l}\text { Explanatory } \\
\text { variables }\end{array}$ & $\mathrm{R}^{2}$ & $F$ & $\mathrm{df}$ & $\mathrm{p}$ & Post-hoc comparisons & $t$ & $\mathrm{p}$ \\
\hline \multirow[t]{2}{*}{$\begin{array}{l}\text { Model } 1 \\
\text { OCs - PC1 } \\
(80 \%)^{\mathrm{a}}\end{array}$} & Wintering area & 0.178 & 16.1 & 2,132 & $<0.001$ & $\begin{array}{l}\text { America vs. Europe } \\
\text { America vs. Africa } \\
\text { Europe vs. Africa }\end{array}$ & $\begin{array}{c}-5.7 \\
- \\
-3.4\end{array}$ & $\begin{array}{r}<0.001 \\
0.003\end{array}$ \\
\hline & $\begin{array}{l}\text { Colony } \\
\text { Sex }\end{array}$ & $\begin{array}{c}\text { ns } \\
0.093\end{array}$ & 16.8 & 1,132 & $<0.001$ & $\begin{array}{l}\text { Bjørnøya vs. Iceland } \\
\text { Bjørnøya vs. Shetland } \\
\text { Iceland vs. Shetland }\end{array}$ & $\begin{array}{l}- \\
- \\
-\end{array}$ & \\
\hline \multirow[t]{2}{*}{$\begin{array}{l}\text { Model } 2 \\
\text { OCs - PC2 } \\
(11 \%)^{\mathrm{a}}\end{array}$} & Wintering area & $\mathrm{ns}$ & & & & $\begin{array}{l}\text { America vs. Europe } \\
\text { America vs. Africa } \\
\text { Europe vs. Africa }\end{array}$ & $\begin{array}{l}- \\
- \\
-\end{array}$ & \\
\hline & Colony & 0.45 & 62 & 2,132 & $<0.001$ & $\begin{array}{l}\text { Bjørnøya vs. Iceland } \\
\text { Bjørnøya vs. Shetland } \\
\text { Iceland vs. Shetland }\end{array}$ & $\begin{array}{r}4.2 \\
10.6 \\
6.6\end{array}$ & $\begin{array}{l}<0.001 \\
<0.001 \\
<0.001\end{array}$ \\
\hline
\end{tabular}



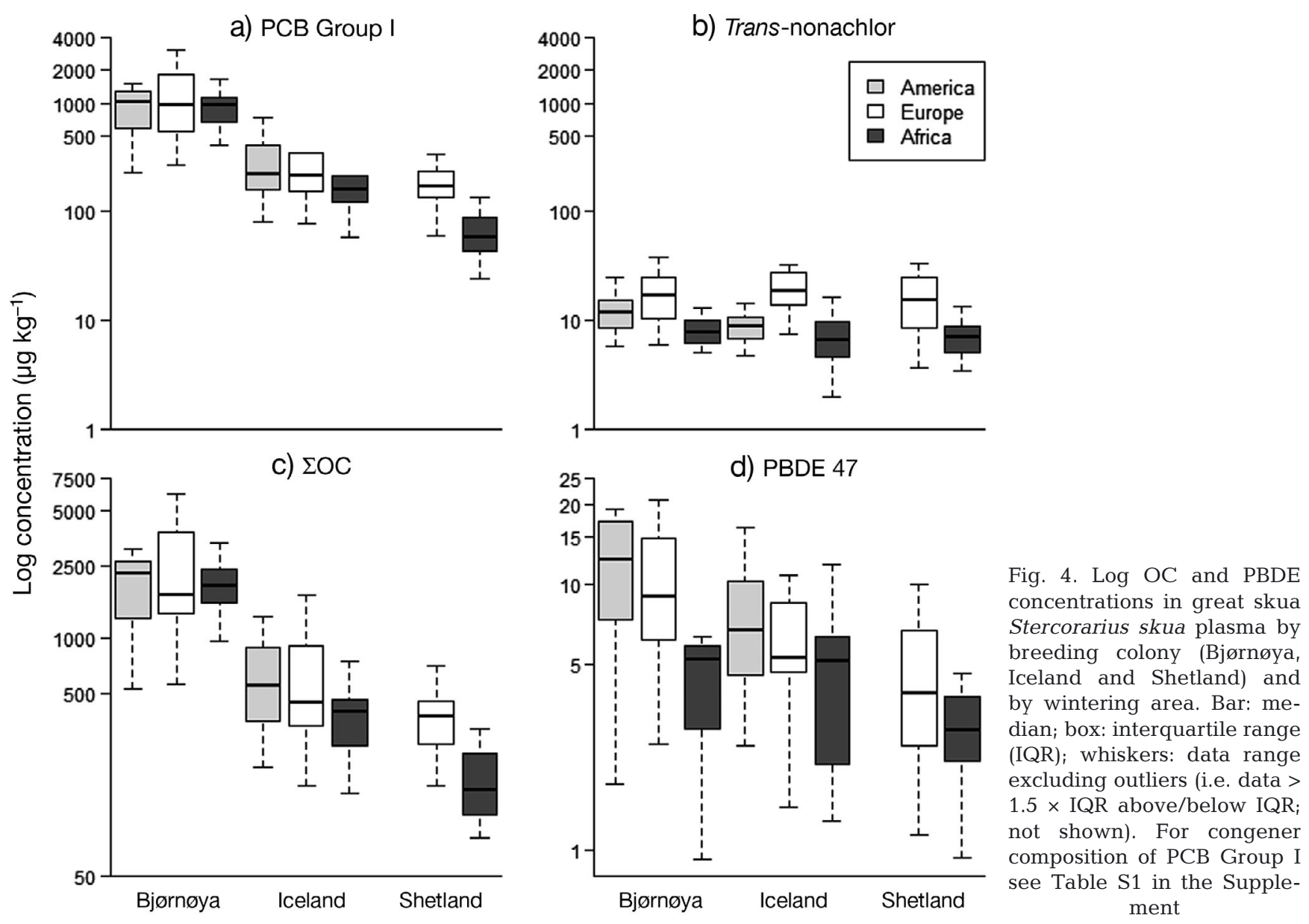

those wintering off America and Europe (Fig. 4). The geometric mean $\Sigma O C$ concentrations in birds wintering off Europe were higher than those wintering off Africa by $4 \%$ for Bjørnøya birds, $39 \%$ for Iceland birds and $102 \%$ for Shetland birds. All breeding colonies were significantly different along PC1, with samples from Bjørnøya containing the highest concentrations of the majority of OCs, followed by those from Iceland and then Shetland (Table 1, Fig. 4 \& Fig. S1a). Amongst birds wintering in Europe, the mean of $\Sigma O C s$ in birds from Iceland were $50 \%$ higher than birds from Shetland and those from Bjørnøya were $280 \%$ higher than those from Iceland. Across all colonies, male birds had higher concentrations of OCs than females, although the differences are small (Fig. S2 in the Supplement). Both breeding colony and wintering area explained variation in $\mathrm{PC} 2$, with higher concentrations of trans-nonachlor in birds wintering in Europe (Fig. 4b). Overall the OC and PBDE concentrations are highly variable even within groups.

Within the breeding colonies of Iceland and Shetland, wintering area explained a significant amount of variation in OC concentrations among individuals ( 7 and $22 \%$ respectively; Table 4 and Fig. S3 in the Supplement). Differences between wintering areas were most evident in birds from Shetland; birds wintering off Europe had higher OC concentrations than birds wintering off Africa (Fig. 4 \& Fig. S3e), with the exception of some OCs found at lower concentrations. Stable isotope ratios of RBCs explained $11 \%$ $\left(\delta^{13} \mathrm{C}\right)$ and $13 \%\left(\delta^{15} \mathrm{~N}\right)$ of the variance in OC concentrations among skuas from Bjørnøya and Iceland respectively (Table 4). However, $\delta^{13} \mathrm{C}$ and $\delta^{15} \mathrm{~N}$ did not show consistent correlations with any OCs across colonies (Fig. S3), and the variation in mean $( \pm \mathrm{SD})$ stable isotope values between individuals was small $\left(\delta^{13} \mathrm{C}=-18.7 \pm 0.4 \%\right.$ and $\left.\delta^{15} \mathrm{~N}=13.5 \pm 0.9 \%\right)$. Stable isotope ratios in feathers and RBCs were significantly correlated $\left(\delta^{15} \mathrm{~N} \rho=0.38, \mathrm{p}<0.001 ; \delta^{13} \mathrm{C} \rho=0.23\right.$, $\mathrm{p}=0.01$ ). As in the analysis of all colonies combined, sex explained a significant amount of variation in OC concentrations. The \%lipid content in plasma did not explain any variation in OC concentrations amongst or within colonies. 
Table 4. Redundancy analysis of organochlorine concentrations and pattern by breeding colony. Sample sizes are smaller than those quoted in Table 1 due to the exclusion of samples with outliers in explanatory variable datasets. For full details on the identification of outliers see 'Materials and methods' section. RBC: red blood cells; ns: not significant

\begin{tabular}{|c|c|c|c|c|c|}
\hline \multirow[t]{2}{*}{ Colony } & \multirow[t]{2}{*}{$\mathrm{n}$} & \multirow{2}{*}{$\begin{array}{l}\text { Expla- } \\
\text { natory } \\
\text { variables }\end{array}$} & \multirow[t]{2}{*}{$\mathrm{p}$} & \multicolumn{2}{|c|}{$\begin{array}{c}\text { Variation } \\
\text { explained (\%) }\end{array}$} \\
\hline & & & & Per variable & Total \\
\hline \multicolumn{6}{|c|}{ Concentration } \\
\hline \multirow[t]{2}{*}{ Bjørnøya } & 43 & $\mathrm{RBC} \delta^{13} \mathrm{C}$ & 0.012 & 11 & 18 \\
\hline & & Sex & 0.042 & 7 & \\
\hline \multirow[t]{3}{*}{ Iceland } & 46 & $\operatorname{RBC} \delta^{15} \mathrm{~N}$ & 0.006 & 13 & 31 \\
\hline & & Sex & 0.004 & 11 & \\
\hline & & Europe & 0.018 & 7 & \\
\hline \multirow[t]{2}{*}{ Shetland } & 42 & Africa & 0.002 & 22 & 27 \\
\hline & & Sex & 0.078 & 5 & \\
\hline \multicolumn{6}{|l|}{ Pattern } \\
\hline Вjørnøуа & 43 & ns & & & \\
\hline \multirow[t]{2}{*}{ Iceland } & 46 & Europe & 0.006 & 20 & 30 \\
\hline & & Sex & 0.048 & 10 & \\
\hline \multirow[t]{2}{*}{ Shetland } & 42 & Sex & 0.01 & 14 & 27 \\
\hline & & Africa & 0.004 & 13 & \\
\hline
\end{tabular}

PBDE concentrations. The number of PBDEs that were detected varied between colonies and wintering areas (Fig. S4 in the Supplement). PBDE 47 was found at the highest concentrations, and was above detection limits in all but 3 samples. There were significant correlations between PBDE 47 concentrations and those of 4 other PBDE congeners (99, 100, 153 and 154) in samples where the latter were above detection limits (PBDE $100 \rho=0.83, \mathrm{p}<0.001$; PBDE $99 \rho=0.77, \mathrm{p}<0.001 ;$ PBDE $154 \rho=0.62, \mathrm{p}<0.001$; PBDE $153 \rho=0.58, \mathrm{p}<0.001$ ). Therefore PBDE 47 was used as a proxy for other PBDEs analysed.

When data from all colonies were pooled, concentrations of PBDE 47 varied significantly with colony $(13 \%)$, wintering area $(8.7 \%)$ and sex $(3.6 \%$; Table 2$)$. There was no interaction between colony and wintering area. PBDE 47 concentrations were highest in birds from Bjørnøya (Fig. 4d, Table 1). Birds wintering off America and Europe had higher concentrations of PBDE 47 compared to those wintering off Africa, but did not differ significantly from each other (Fig. 4d, Table 3). Males had significantly higher concentrations of PBDE 47 than females (Table 2, geometric means $\pm \mathrm{SD}_{i}$ Bjørnøya males $15.5 \pm 50$, females $6.94 \pm$ 13.9; Iceland males $6.37 \pm 17.6$, females $5.18 \pm 10.1$; Shetland males $3.73 \pm 6.04$, and females $3.14 \pm 5.33$ ).

Within colonies, wintering area explained a significant amount of variation in concentrations of PBDE 47 in birds from Bjørnøya $\left(F_{2,40}=3.6, \mathrm{p}=0.04\right)$ and Shetland $\left(F_{1,43}=7.4, \mathrm{p}=0.01\right)$. Birds from Bjørn- øya that wintered off Africa had lower concentrations of PBDE 47 than those wintering off America ( $p=$ 0.03 ) and those from Shetland that wintered off Africa had lower concentrations of PBDE $47(p=0.01)$ compared to those wintering off Europe; no other comparisons were significant (Tables 1, 2 \& 3). Among birds from Iceland there was an effect of sex on concentrations of PBDE $47\left(F_{1,48}=5.9, \mathrm{p}=0.02\right)$, with males having higher concentrations than females (Fig. S2d), but no effect of wintering area.

OCs pattern. In a PCA of OC pattern, 80 and $11 \%$ of variation was explained by PC1 and PC2, respectively. $p, p^{\prime}$-DDE was positively correlated with PC1, increasing as a proportion of $\Sigma O C s$, whilst PCB Group I was negatively correlated with PC1. Likewise along $\mathrm{PC} 2$, trans-nonachlor increased as a proportion of $\Sigma O C s$ as oxychlordane decreased (see Fig. S1b). Concentrations of these OCs are presented as a proportion of $\Sigma$ OCs in Fig. 5.

Wintering area and sex explained significant variation in pattern in PC1, 17.8\% and 9.3\% respectively (Table 3). The pattern of OCs in birds wintering off Europe was significantly different from those wintering off America and Africa. This was driven by a higher proportion of PCB Group I and a lower proportion of $p, p^{\prime}$-DDE in birds wintering in Europe (Fig. 5a,b). Males also had a higher proportion of PCB Group I in their OC load than females (Fig. S5b in the Supplement). Colony explained $45 \%$ of variation in PC2 and sex explained 3\% (Table 3) with all colonies differing along this axis $(\mathrm{p}<0.001)$. The OC pattern along PC2 in birds from Bjørnøya was dominated by a higher proportion of PCB Group I, mirex and oxychlordane whereas proportions of the remaining OCs were higher in birds from Shetland, and intermediate in those from Iceland (Fig. S3 \& Fig. 5). Males had a lower proportion of most OCs correlated with $\mathrm{PC} 2$, with the exception of PCB Group I, mirex and oxychlordane.

Within colony, wintering off Europe accounted for $20 \%$ of variation in POP pattern in birds from Iceland (Table 4). This was driven by proportionally higher PCB Group I concentrations and lower $p, p^{\prime}$-DDE and oxychlordane (Fig. S3d). Trans-nonachlor and PCB groups II, IV and V, correlated with PC2, were also higher in birds from Iceland wintering off Europe. Among birds from Shetland, $13 \%$ of the variation in pattern was explained by wintering area; again, proportions of PCB Group I were higher and $p, p^{\prime}$-DDE were lower in birds that wintered in Europe (Fig. S3f). Wintering area was unrelated to the variation in OC pattern in birds from Bjørnøya, nor was any other variable significant (Fig. S3b). Sex accoun- 


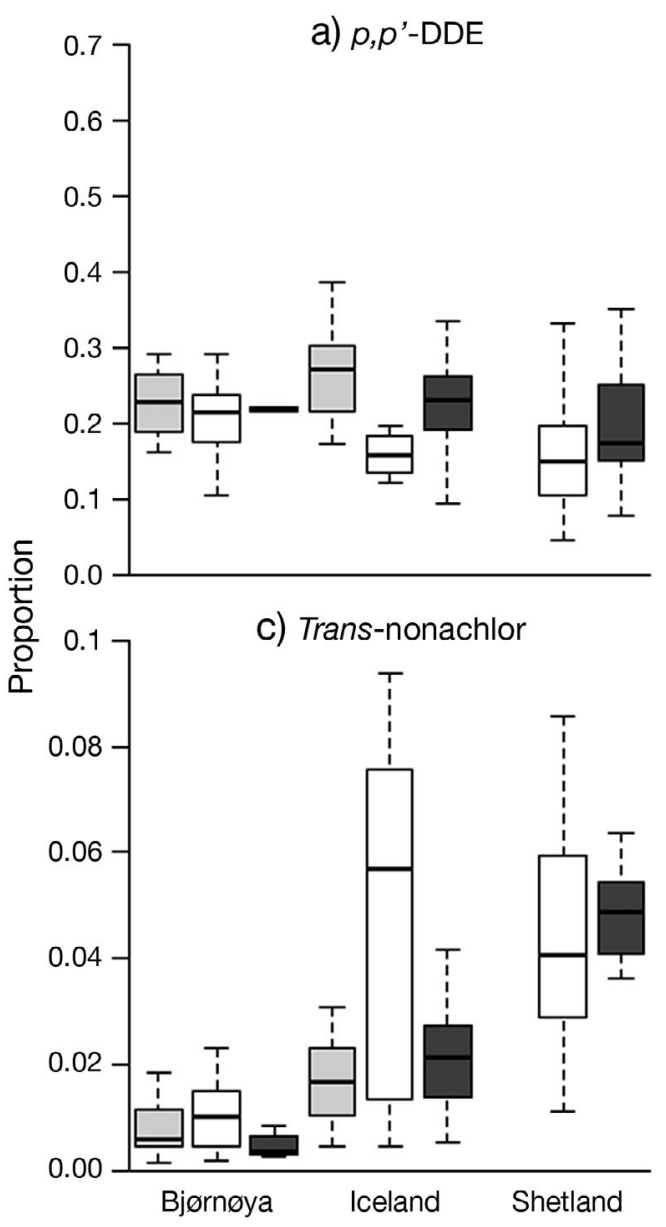

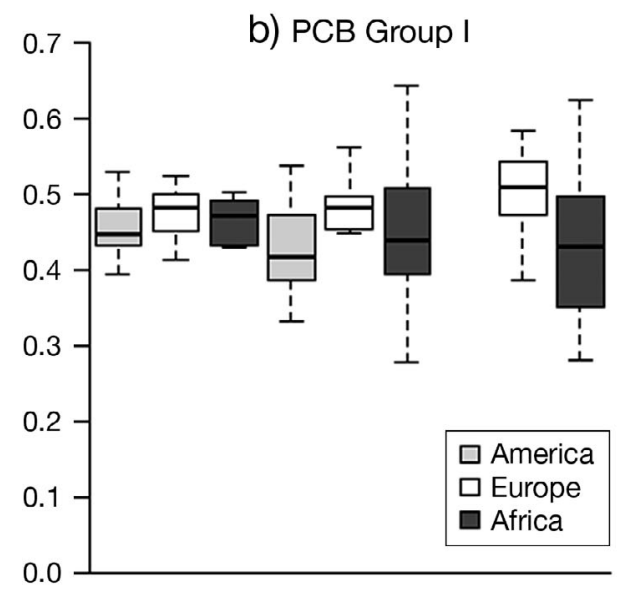

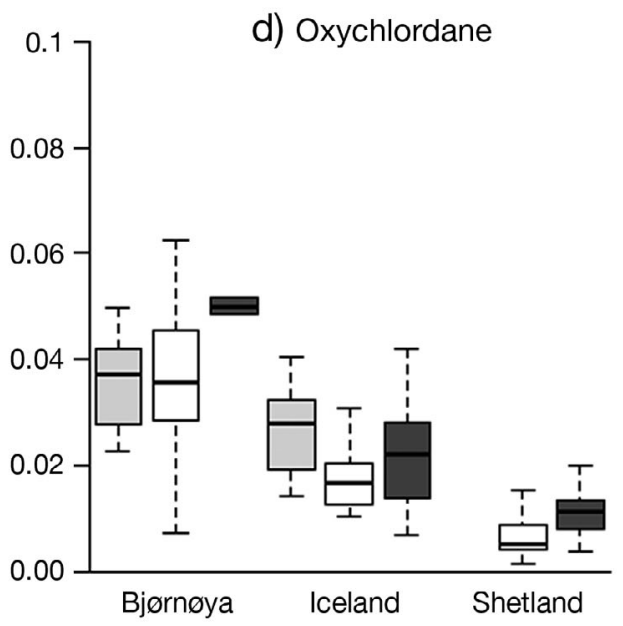

Fig. 5. Individual OCs as a proportion of $\Sigma \mathrm{OCs}$ in great skua Stercorarius skua plasma by wintering area (America, Europe and Africa) and breeding colony (Bjørnøya, Iceland and Shetland). Boxplot limits as in Fig. 4 ted for 10 and $14 \%$ of variation in OC pattern in birds from Iceland and Shetland, respectively; males had a higher proportion of PCB Group I (Fig. S3d,f). Neither \%lipids nor the stable isotopes values of RBCs explained variation in pattern of OCs.

\section{DISCUSSION}

\section{Wintering area influence}

To our knowledge this study is the first to show a significant influence of wintering area on both concentration and pattern of pollutants in plasma of a seabird sampled during the breeding period. Our findings support assertions that differences between migratory and resident seabird species breeding in the same location might reflect accumulation of pollutants during the non-breeding season (Corsolini et al. 2011). Likewise, in a study of loggerhead turtles Caretta caretta, migrant males had different concentrations and patterns of OCs and PBDEs compared with residents along the eastern seaboard of the USA (Ragland et al. 2011). Few studies have used tracking data to investigate the influence of wintering area on POPs in birds and these have focused on terrestrial and coastal species, rather than marine (Henny \& Blus 1986, Elliott et al. 2007, Yates et al. 2010). A radio-tracking study of black-crowned night-herons Nycticorax nycticorax found higher DDE concentrations in the eggs of a population wintering in the southern USA, compared to a population wintering in Mexico (Henny \& Blus 1986). Similarly, in the white-faced ibis Plegadis chihi plasma DDE concentrations at the breeding site were significantly correlated with DDE concentrations in prey sampled in their wintering areas (Yates et al. 2010). In contrast no effect of wintering area was found on concentrations of DDE in osprey Pandion haliaetus eggs from the Pacific northwest (Elliott et al. 2007). In the present study, concentrations of DDE were affected more by breeding colony than wintering area.

Despite plasma being a transient matrix containing POPs from an individual's current diet, we were able 
to detect the effect of wintering area on plasma concentration in the breeding season. This may be due to the long half-lives of many POPs in plasma (Drouillard et al. 2001) or to remobilisation of body lipid stores containing POPs to meet the energetic requirements of the breeding season (Bustnes et al. 2012).

In birds from Bjørnøya there was no effect of wintering area on $\mathrm{OC}$ concentrations or pattern. In contrast to the other colonies, in Bjørnøya there were significant differences in the sex ratio of birds using different wintering areas, with most males wintering off America. However, since, in this study, males had higher concentrations of OCs than females and birds which wintered off America were associated with high OC concentrations, any differences between wintering areas should have been accentuated rather than obscured in the Bjørnøya population. Analysis of prey remains indicates that great skuas in Bjørnøya consumed a diet consisting mostly of seabirds (Knutsen 2010, Leat 2013), whilst birds from the other 2 colonies consumed more fish (Leat 2013). Higher $\delta^{15} \mathrm{~N}$ ratios of RBCs in birds from Bjørnøya also suggest they were feeding at a higher trophic level. Thus birds from Bjørnøya might be expected to accumulate more OCs during the breeding season than those from other colonies, obscuring differences between less contaminated wintering area sources. Supporting this hypothesis, compared to other breeding colonies, birds from Bjørnøya had the highest concentrations and greatest variability in OCs. However, contamination near the breeding colony relative to wintering area may differ between pollutants, due to different temporal and spatial emission patterns. This is evident in the significantly lower concentrations of PBDE 47 in birds from Bjørnøya that wintered off northwest Africa compared with those off America and Europe. The lack of influence of wintering area detected in $\mathrm{OC}$ concentrations of birds from Bjørnøya may also be the result of small sample sizes for particular wintering areas, as also observed in osprey eggs (Elliott et al. 2007).

In this study wintering area had a greater effect on pattern than on concentration of OCs across great skua colonies. The use of POP pattern rather than concentration for determining the influence of time spent in wintering areas may reduce the impact of confounding biological factors such as age and lipid content, and reduces problems posed by interlaboratory variation in concentration measurements (Dickhut et al. 2009). However, this approach would prove less useful in accessing the relative risks of contaminant exposure associated with wintering in different areas.

\section{Differences in POPs between wintering area}

Lower OC concentrations in birds from Iceland and Shetland that wintered off northwest Africa probably reflect lower historical emissions in that region compared to Europe and North America (Breivik et al. 2004). The congener composition of recent emissions of PCBs more closely resembles those found in industrial mixtures of PCBs, with a higher proportion of less persistent lower chlorinated PCBs, as these have not yet had sufficient time to be modified by biological processes. Therefore the higher proportion congeners in PCB groups IV and V in birds wintering off Africa may reflect more recent atmospheric sources of PCBs in west Africa from contaminated waste (Gioia et al. 2011). There is a general lack of studies on regional variation in POPs across the same spatial scale with which to compare the present study, in part due to the limited number of species with sufficient spatial distribution. PCB concentrations in Calonectris shearwaters increased from south to north in the eastern Atlantic with a higher proportion of lower chlorinated PCBs in the more southerly colonies (Roscales et al. 2010), in agreement with this study. In addition Mediterranean monk seals Monachus monachus from the Western Sahara coast had PCB concentrations an order of magnitude lower (Borrell et al. 2007) than those found in harbour seals Phoca vitulina in Europe and North America (Aguilar et al. 2002).

Concentrations of DDT and its metabolites were proportionally higher in great skuas wintering off northwest Africa and America than those wintering off Europe. This might reflect continuing restricted use of DDT for control of disease vectors (Barnhoorn et al. 2009) at lower latitudes. In the northwest Atlantic, the Gulf stream is thought to be an important secondary source of DDT (Stemmler \& Lammel 2009), which may contribute to higher concentrations of DDT and DDE in birds wintering off America, although one cannot exclude the influence of dietary factors. The greater contribution of DDE and PCB Group I to the pattern of OCs may reflect their comparatively long half-lives in biota (Clark et al. 1987, Drouillard et al. 2001). Great skuas that wintered off southwest Europe showed higher concentration of the pesticide trans-nonachlor; however, we are unable to suggest a likely cause of this phenomenon.

Concentrations of PBDE 47 and detection rates of 4 other penta- and hexa-PBDEs were lower in birds wintering off Africa than those wintering in other areas. No substantial production of PBDEs is known for west Africa (Alaee et al. 2003), and higher con- 
centrations in Europe and America may also reflect higher usage of PBDEs in these regions due to more rigorous fire safety legislation (Jaward et al. 2004). Higher concentrations of $\Sigma$ PBDEs were found in seawater in the English Channel than off northwest Africa (Xie et al. 2011), but we know of no comparison of concentrations in biota.

\section{Other variables affecting the accumulated OCs in great skuas}

In addition to colony (the most important explanatory variable) and wintering area, sex was the only other variable which was consistently significant in explaining variation in POPs. The effect of sex is small in comparison to colony and therefore may only be detectable with large sample sizes. Males had higher concentrations of most OCs and PBDE 47 across colonies and the pattern of OCs in males was dominated by a higher proportion of persistent PCBs compared to females. This is similar to findings in other seabird species (Bustnes et al. 2003, 2007) and is probably due to transfer of POPs by females via egg laying (Bourgeon et al. 2013).

Diet in breeding colony as measured by $\delta^{15} \mathrm{~N}$ and $\delta^{13} \mathrm{C}$ in RBCs was not consistent in explaining variation in POPs. Despite the variety of prey consumed by great skuas (Furness 1987), the variation in RBC stable isotopes within colony was relatively small. Accordingly, $\delta^{15} \mathrm{~N}$ of great skua eggs was only weakly correlated with OC concentrations (Leat et al. 2011). This finding is not unusual as a significant effect of $\delta^{15} \mathrm{~N}$ on POP levels is often only found at an ecosystem scale (Borgå et al. 2012) although significant relationships were reported between $\delta^{15} \mathrm{~N}$ and OC levels in both marine (Elliott et al. 2009) and terrestrial birds (Elliott et al. 2012). It is possible there may be a mismatch between the time period represented by RBC stable isotopes (half-life $\sim 15 \mathrm{~d}$; Bearhop et al. 2002) and the length of time over which pollutants may be present in the blood ( $>1 \mathrm{yr}$ for some OCs; Clark et al. 1987).

\section{Wintering area and duration of breeding area residence}

By comparing stable isotope ratios in feathers taken from birds tracked using geolocators with those from a much larger sample of untracked birds, it was possible to assign the great majority of the latter group to 1 of 3 isotopically-distinct wintering regions. Although no tracked birds from Bjørnøya used this study had wintered off Africa in 2008-09, several birds were assigned to this wintering area based on their feather stable isotope ratios. The use of this wintering area by birds breeding in Bjørnøya was confirmed by a logger recovered in 2010 which indicated that this bird had wintered off Africa in both the 2008-09 and 2009-10 winters (Magnusdottir et al. 2012).

Variation in stable isotope ratios in predator tissues results from variation in environmental baselines, food web structure or differences in diet among regions (Bearhop et al. 2001, Phillips et al. 2009, González-Solís et al. 2011). The $\delta^{13} \mathrm{C}$ values of great skuas that wintered off northwest Africa were consistent with their use of the highly productive Canary Current upwelling system (Heileman \& Tanstad 2008). Here, our data suggests the baseline is enriched in $\delta^{13} \mathrm{C}$ in comparison with the wintering area off Europe. There may also be differences in diet, although the largely overlapping $\delta^{15} \mathrm{~N}$ in feathers of birds that wintered in the 3 areas suggests no clear pattern with respect to trophic position. Very little is known about the diet of great skuas during the winter due to their pelagic lifestyle, other than reports that some follow fishing vessels (Camphuysen \& van der Meer 2005). Given that great skuas spend more than half the year away from their breeding colony this is a considerable gap in our knowledge of potential sources of contamination.

\section{Issues with identification of wintering areas}

The ordination diagrams of PCAs grouped some samples, based on their OC concentrations and patterns, with wintering areas other than those classified by stable isotopes. This may be due to differences in diet within a wintering area, leading to high variability in OCs and/or isotopes, or due to misclassification of wintering areas of birds. A more likely explanation is that the present study's classification of wintering areas was an over-simplification of migratory behaviour in great skuas. Of the birds tracked with loggers, $15 \%$ wintered in more than one area. In addition, wintering areas identified by geolocation data were only defined for a 3 mo wintering period, but birds may be away from the colony for up to $7.5 \mathrm{mo}$. Examination of geolocation data indicates that some birds make late-winter movements away from their core winter quarters. For example, 2 birds from Shetland, one of which wintered in both Europe and Africa, and the other wintered only in Africa, moved to a longitude of $\sim 40^{\circ} \mathrm{W}$ in late March, where they re- 
mained for about 1 mo until their return to the colony. The latitude could not be determined as this was during the equinox period. Moreover, there is a temporal mismatch between the accumulation of POPs, which is a dynamic process, and stable isotope ratios in a single primary feather which provide information on location during the period of active feather growth.

More accurate information about migration and wintering area can be gained from deploying alternative devices (satellite-transmitters or GPS devices) which are unaffected by equinox periods. However, deploying enough devices to match the sample size available in this study $(\mathrm{n}=141)$ is not cost-effective, and, unlike geolocators, their long-term attachment requires the use of a harness, which has resulted in high mortality rates in previous studies of seabirds (Phillips et al. 2003). A more thorough investigation of variation in stable isotopes across all primary feathers, by taking a small sample from each primary along the wing, might help assess location for a larger proportion of the time away from the colony (see González-Solís et al. 2011). This, in conjunction with a larger sample size of tracked birds to improve wintering area classifications, could provide a more detailed picture of individual movement patterns.

\section{Implications of study findings}

Evidence that wintering area has an effect on POP concentrations in breeding great skuas has implications for other ecotoxicology studies. For example pollutants measured in eggs are often used to monitor temporal trends (Helgason et al. 2008, Pereira et al. 2009) and although sampling at the same colony controls for spatial differences in exposure over time, the effect of wintering area or changes in migration strategy cannot be accounted for. Although the effect of wintering area on egg concentrations has not been measured directly in great skuas, $\mathrm{OCC}$ concentrations were $50 \%$ higher in chicks of females from Shetland who wintered in Europe compared to the chicks of females who wintered in Africa (Bourgeon et al. 2013). Appropriate consideration of the effect of different migration strategies may introduce an additional layer of complexity when selecting species and matrices for long-term monitoring of pollutants, especially as some seabirds may themselves feed on migratory prey. In addition, the contribution of pollutant exposure during the winter may have a greater role to play in the global transportation of pollutants than is currently appreciated and can help explain the high variability in POP concentrations within colonies.
Acknowledgements. This study was supported by the Research Council of Norway, grant number 184830. Fieldwork in Shetland was carried out under licence from the UK Home Office and bird trapping and ringing permits from the British Trust for Ornithology. We thank Scottish Natural Heritage and the Holbourn family for permission to work in Foula. Fieldwork in Bjørnøya was carried out under permit from the Governor of Svalbard, Stavanger Museum and the Directorate for Nature Management. Fieldwork in Iceland was carried out under licence from the Icelandic Institute of Natural History, Reykjavik. We thank all those who assisted with fieldwork.

\section{LITERATURE CITED}

Aguilar A, Borrell A, Reijnders PJH (2002) Geographical and temporal variation in levels of organochlorine contaminants in marine mammals. Mar Environ Res 53:425-452

> Alaee M, Arias P, Sjodin A, Bergman A (2003) An overview of commercially used brominated flame retardants, their applications, their use patterns in different countries/ regions and possible modes of release. Environ Int 29: 683-689

Antweiler RC, Taylor HE (2008) Evaluation of statistical treatments of left-censored environmental data using coincident uncensored data sets: I. Summary statistics. Environ Sci Technol 42:3732-3738

Barnhoorn IEJ, Bornman MS, van Rensburg CJ, Bouwman $H$ (2009) DDT residues in water, sediment, domestic and indigenous biota from a currently DDT-sprayed area. Chemosphere 77:1236-1241

> Bearhop S, Thompson DR, Phillips RA, Waldron S and others (2001) Annual variation in great skua diets: the importance of commercial fisheries and predation on seabirds revealed by combining dietary analyses. Condor 103: 802-809

> Bearhop S, Waldron S, Votier SC, Furness RW (2002) Factors that influence assimilation rates and fractionation of nitrogen and carbon stable isotopes in avian blood and feathers. Physiol Biochem Zool 75:451-458

- Best DA, Elliott KH, Bowerman WW, Shieldcastle $M$ and others (2010) Productivity, embryo and eggshell characteristics, and contaminants in bald eagles from the Great Lakes, USA, 1986 to 2000. Environ Toxicol Chem 29: 1581-1592

Borgå K, Gabrielsen GW, Skaare JU, Kleivane L, Norstrom RJ, Fisk AT (2005a) Why do organochlorine differences between arctic regions vary among trophic levels? Environ Sci Technol 39:4343-4352

> Borgå K, Wolkers H, Skaare JU, Hop H, Muir DCG, Gabrielsen GW (2005b) Bioaccumulation of PCBs in Arctic seabirds: influence of dietary exposure and congener biotransformation. Environ Pollut 134:397-409

> Borgå K, Kidd KA, Muir DCG, Berglund O and others (2012) Trophic magnification factors: considerations of ecology, ecosystems, and study design. Integr Environ Assess Manag 8:64-84

Borrell A, Cantos G, Aguilar A, Androukaki E, Dendrinos P (2007) Concentrations and patterns of organochlorine pesticides and PCBs in Mediterranean monk seals (Monachus monachus) from Western Sahara and Greece. Sci Total Environ 381:316-325

Bourgeon S, Leat EKH, Furness RW, Borgå K, Hanssen SA, Bustnes JO (2013) Dietary versus maternal sources of 
organochlorines in top predator seabird chicks: an experimental approach. Environ Sci Technol 47:5963-5970

Breivik K, Alcock R, Li YF, Bailey RE, Fiedler H, Pacyna JM (2004) Primary sources of selected POPs: regional and global scale emission inventories. Environ Pollut 128: 3-16

Buckman AH, Norstrom RJ, Hobson KA, Karnovsky NJ, Duffe J, Fisk AT (2004) Organochlorine contaminants in seven species of Arctic seabirds from northern Baffin Bay. Environ Pollut 128:327-338

Bustnes JO, Erikstad KE, Skaare JU, Bakken V, Mehlum F (2003) Ecological effects of organochlorine pollutants in the Arctic: a study of the glaucous gull. Ecol Appl 13: 504-515

> Bustnes JO, Tveraa T, Varpe O, Henden JA, Skaare JU (2007) Reproductive performance and organochlorine pollutants in an Antarctic marine top predator: the south polar skua. Environ Int 33:911-918

Bustnes JO, Moe B, Hanssen SA, Herzke D and others (2012) Temporal dynamics of circulating persistent organic pollutants in a fasting seabird under different environmental conditions. Environ Sci Technol 46: 10287-10294

Camphuysen CJ, van der Meer J (2005) Wintering seabirds in West Africa: foraging hotspots off Western Sahara and Mauritania driven by upwelling and fisheries. Afr J Mar Sci 27:427-437

Clark TP, Norstrom RJ, Fox GA, Won HT (1987) Dynamics of organochlorine compounds in herring gulls (Larus argentatus): II. A two-compartment model and data for 10 compounds. Environ Toxicol Chem 6:547-559

> Corsolini S, Borghesi N, Ademollo N, Focardi S (2011) Chlorinated biphenyls and pesticides in migrating and resident seabirds from East and West Antarctica. Environ Int 37:1329-1335

> Daley JM, Leadley TA, Drouillard KG (2009) Evidence for bioamplification of nine polychlorinated biphenyl (PCB) congeners in yellow perch (Perca flavascens) eggs during incubation. Chemosphere 75:1500-1505

de Wit C, Fisk AT, Hobbs K, Muir D and others (2004) Arctic pollution 2002: persistent organic pollutants in the Arctic. Arctic Monitoring and Assessment Program, Oslo. www. amap.no/documents/doc/arctic-pollution-2002/6

Dickhut RM, Deshpande AD, Cincinelli A, Cochran MA and others (2009) Atlantic bluefin tuna (Thunnus thynnus) population dynamics delineated by organochlorine tracers. Environ Sci Technol 43:8522-8527

> Drouillard KG, Fernie KJ, Smits JE, Bortolotti GR, Bird DM, Norstrom RJ (2001) Bioaccumulation and toxicokinetics of 42 polychlorinated biphenyl congeners in American kestrels (Falco sparverius). Environ Toxicol Chem 20: 2514-2522

> Drouillard KG, Hagen H, Haffner GD (2004) Evaluation of chloroform/methanol and dichloromethane/hexane extractable lipids as surrogate measures of sample partition capacity for organochlorines in fish tissues. Chemosphere 55:395-400

Egevang C, Stenhouse IJ, Phillips RA, Petersen A, Fox JW, Silk JRD (2010) Tracking of Arctic terns Sterna paradisaea reveals longest animal migration. Proc Natl Acad Sci USA 107:2078-2081

Elliott JE, Morrissey CA, Henny CJ, Inzunza ER, Shaw P (2007) Satellite telemetry and prey sampling reveal contaminant sources to Pacific Northwest ospreys. Ecol Appl $17: 1223-1233$
Elliott KH, Cesh LS, Dooley JA, Letcher RJ, Elliott JE (2009) PCBs and DDE, but not PBDEs, increase with trophic level and marine input in nestling bald eagles. Sci Total Environ 407:3867-3875

$>$ Elliott JE, Levac J, Guigueno MF, Shaw DP and others (2012) Factors influencing legacy pollutant accumulation in alpine osprey: Biology, topography, or melting glaciers? Environ Sci Technol 46:9681-9689

Fisk AT, Moisey J, Hobson KA, Karnovsky NJ, Norstrom RJ (2001) Chlordane components and metabolites in seven species of Arctic seabirds from the Northwater Polynya: relationships with stable isotopes of nitrogen and enantiomeric fractions of chiral components. Environ Pollut 113:225-238

> Fridolfsson AK, Ellegren H (1999) A simple and universal method for molecular sexing of non-ratite birds. J Avian Biol 30:116-121

Furness RW (1987) The skuas. T \& AD Poyser, Calton

Gaston AJ (2004) Seabirds: a natural history. T \& AD Poyser, London

Gioia R, Eckhardt S, Breivik K, Jaward FM, Prieto A, Nizzetto L, Jones KC (2011) Evidence for major emissions of PCBs in the west African region. Environ Sci Technol 45:1349-1355

González-Solís J, Smyrli M, Militão T, Gremillet D, Tveraa T, Phillips RA, Boulinier T (2011) Combining stable isotope analyses and geolocation to reveal kittiwake migration. Mar Ecol Prog Ser 435:251-274

Griffiths R, Double MC, Orr K, Dawson RJG (1998) A DNA test to sex most birds. Mol Ecol 7:1071-1075

> Hebert CE, Bur M, Sherman D, Shutt JL (2008) Sulfur isotopes link overwinter habitat use and breeding condition in double-crested cormorants. Ecol Appl 18:561-567

Heileman S, Tanstad M (2008) I-3 Canary Current: LME \#27. United Nations Environmental Programme, Nairobi

Helgason LB, Barrett R, Lie E, Polder A, Skaare JU, Gabrielsen GW (2008) Levels and temporal trends (1983-2003) of persistent organic pollutants (POPs) and mercury (Hg) in seabird eggs from Northern Norway. Environ Pollut 155:190-198

Helsel DR (2004) Nondetects and data analysis: statistics for censored environmental data. John Wiley \& Sons, New York, NY

Henny CJ, Blus LJ (1986) Radiotelemetry locates wintering grounds of DDE-contaminated black-crowned nightherons. Wildl Soc Bull 14:236-241

> Henriksen EO, Gabrielsen GW, Skaare JU (1998) Validation of the use of blood samples to assess tissue concentrations of organochlorines in glaucous gulls, Larus hyperboreus. Chemosphere 37:2627-2643

> Hobson KA, Clark RG (1992) Assessing avian diets using stable isotopes II: factors influencing diet-tissue fractionation. Condor 94:189-197

Jardine TD, Kidd KA, Fisk AT (2006) Applications, considerations, and sources of uncertainty when using stable isotope analysis in ecotoxicology. Environ Sci Technol 40:7501-7511

Jaward FM, Farrar NJ, Harner T, Sweetman AJ, Jones KC (2004) Passive air sampling of PCBs, PBDEs, and organochlorine pesticides across Europe. Environ Sci Technol 38:34-41

Knutsen AE (2010) Diet and breeding success of great skuas (Stercorarius skua) on Bjørnøya, Norway. Masters thesis, Norwegian University of Life Science, Aas

Lazar R, Edwards RC, Metcalfe CD, Metcalfe T, Gobas F, 
Haffner GD (1992) A simple, novel method for the quantitative analysis of coplanar (non-ortho substituted) polychlorinated biphenyls in environmental samples. Chemosphere 25:493-504

Leat EHK (2013) Persistent organic pollutants in great skuas Stercorarius skua. PhD thesis, Glasgow University. http://theses.gla.ac.uk/1492

Leat EHK, Bourgeon S, Borgå K, Strøm H and others (2011) Effects of environmental exposure and diet on levels of persistent organic pollutants (POPs) in eggs of a top predator in the North Atlantic in 1980 and 2008. Environ Pollut 159:1222-1228

Leat EHK, Bourgeon S, Eze JI, Muir DCG and others (2013) Perfluoroalkyl substances in eggs and plasma of an avian top predator, great skua (Stercorarius skua), in the north Atlantic. Environ Toxicol Chem 32:569-576

Lepš J, Šmilauer P (2003) Multivariate analysis of ecological data using CANOCO, Vol 1. Cambridge University Press, Cambridge

> Magnusdottir E, Leat EHK, Bourgeon S, Strom H and others (2012) Wintering areas of great skuas Stercorarius skua breeding in Scotland, Iceland and Norway. Bird Study 59:1-9

Michalik A, McGill RAR, Furness RW, Eggers T, van Noordwijk HJ, Quillfeldt P (2010) Black and white-does melanin change the bulk carbon and nitrogen isotope values of feathers? Rapid Commun Mass Spectrom 24: 875-878

Newman MC (2010) Fundamentals of ecotoxicology, Vol 1. CRC Press, Boca Raton, FL

Pereira MG, Walker LA, Best J, Shore RF (2009) Long-term trends in mercury and PCB congener concentrations in gannet (Morus bassanus) eggs in Britain. Environ Pollut 157:155-163

Phillips RA, Xavier JC, Croxall JP (2003) Effects of satellite transmitters on albatrosses and petrels. Auk 120: 1082-1090

Phillips RA, Catry P, Silk JRD, Bearhop S, McGill R, Afanasyev V, Strange IJ (2007) Movements, winter distribution and activity patterns of Falkland and brown skuas: insights from loggers and isotopes. Mar Ecol Prog Ser 345:281-291

Phillips RA, Bearhop S, McGill RAR, Dawson DA (2009) Stable isotopes reveal individual variation in migration strategies and habitat preferences in a suite of sea-

Editorial responsibility: Jacob González-Solís, Barcelona, Spain birds during the nonbreeding period. Oecologia 160: 795-806

Post DM (2002) Using stable isotopes to estimate trophic position: models, methods, and assumptions. Ecology 83: 703-718

R Core Development Team (2011) R: A language and environment for statistical computing. R Foundation for Statistical Computing, Vienna

Ragland JM, Arendt MD, Kucklick JR, Keller JM (2011) Persistent organic pollutants in blood plasma of satelittetracked adult male loggerhead sea turtles (Caretta caretta). Environ Toxicol Chem 30:1549-1556

Roscales JL, Munoz-Arnanz J, González-Solís J, Jimenez B (2010) Geographical PCB and DDT patterns in shearwaters (Calonectris sp.) breeding across the NE Atlantic and the Mediterranean Archipelagos. Environ Sci Technol 44:2328-2334

> Stemmler I, Lammel G (2009) Cycling of DDT in the global environment 1950-2002: world ocean returns the pollutant. Geophys Res Lett 36:L24602, doi:10.1029/2009 GL041340

Ter Braak CJF, Šmilauer P (2002a) CANOCO for Windows: Software for Community Ordination, Version 4.5. Microcomputer Power, Ithaca, NY

Ter Braak CJF, Šmilauer P (2002b) CANOCO reference manual and user's guide to CANOCO for Windows, Vol 1. Microcomputer Power, Ithaca, NY

UNEP (2001) United Nations Environment Programme, Stockholm convention on persistent organic pollutants. http://chm.pops.int/Convention/ConventionText/tabid/ 2232/Default.aspx

UNEP (2009) United Nations Environment Programme, Stockholm convention on persistent organic pollutants. http://chm.pops.int/Convention/ConventionText/tabid/ 2232/Default.aspx

Venables WN, Ripley BD (2002) Modern applied statistics with S, Vol 1. Springer, New York, NY

> Xie Z, Moeller A, Ahrens L, Sturm R, Ebinghaus R (2011) Brominated flame retardants in seawater and atmosphere of the Atlantic and the Southern Ocean. Environ Sci Technol 45:1820-1826

> Yates MA, Fuller MR, Henny CJ, Seegar WS, Garcia J (2010) Wintering area DDE source to migratory white-faced ibis revealed by satellite telemetry and prey sampling. Ecotoxicology 19:153-162

Submitted: July 23, 2012; Accepted: June 22, 2013

Proofs received from author(s): September 22, 2013 